\title{
Angiolymphoid hyperplasia with eosinophilia: possible aetiological role for immunisation
}

\author{
LAVINIA A HALLAM, * G A MACKINLAY, $\dagger$ ANNE M A WRIGHT* \\ From the Departments of *Pathology and + Paediatric Surgery, Royal Hospital for Sick Children, Edinburgh, \\ Scotland
}

SUMMARY Five young children (mean age 26.4 months) with angiolymphoid hyperplasia with eosinophilia (Kimura's disease) from either the upper arm or buttock were identified over 18 months. The unusual distribution of the lesions and the young age of the patients suggested a possible association with immunisation. The clinical and histopathological features in these cases were accordingly reviewed. The biopsy specimens showed the usual histological appearances of a prominent inflammatory component, fibrosis, and vascular proliferation associated with aggregates of eosinophils. The features were those of a reactive rather than neoplastic process. Immunohistochemical preparations showed positive staining of variable numbers of plasma cells with antibodies to IgG, IgM, IgA and IgE and a reticular staining of germinal centres with IgM and IgE antibodies.

Immunisation histories obtained from the patients' general practitioners showed a remarkable correlation between the distribution of the lesions and the sites of injections and an aetiological role for immunisation in these cases seems likely.

Over the past decade angiolymphoid hyperplasia with eosinophilia has emerged as a recognised entity featuring vascular proliferation and an inflammatory reaction, often with numerous eosinophils. ${ }^{12}$ Kimura's disease is probably a closely related condition. ${ }^{3}$ The aetiology remains obscure, although workers favour either a neoplastic ${ }^{4}$ or reactive process. ${ }^{5}$ In typical cases, presentation is usually in young adults with either solitary or multiple subcutaneous nodules on the head and neck, particularly the periauricular regions. ${ }^{2}$ Other sites have also been recorded and some lesions have been described in deep tissues. ${ }^{6-10}$

We report five patients who were admitted to our hospital over a period of 18 months in whom a histological diagnosis of angiolymphoid hyperplasia with eosinophilia was made. All showed the typical histological appearances. The clinical presentations were, however, rather unusual and certain aspects suggested a possible aetiological role of immunisation in these cases.

\section{Patients and methods}

Five patients were referred to the Royal Hospital for Sick Children in Edinburgh; four male and one female

Accepted for publication 12 April 1989 with ages ranging from 13-34 months (mean age 26.4 months). The clinical details of these patients are presented in table 1 . The main findings were of irregular subcutaneous nodules $(0.5-1 \mathrm{~cm}$ in diameter) which were itchy, sometimes fluctuated in size, and were tender. There was some discolouration of the overlying skin.

In four of the cases the lesions were present either on the upper part of the buttock or upper arm. In one case (case 5) two lesions were present; one on the right buttock and one on the left flank. The mother volunteered that she thought the lesions had developed shortly after immunisation. This and the rather unusual distribution of the lesions in the other cases raised the possibility of an aetiological role for immunisation. The respective general practitioners were approached and immunisation histories were obtained for each patient (table 1). All the immunisations were given at the "appropriate ages". Eosinophil counts were obtained in four out of the five cases. Serum IgE concentrations were, unfortunately, not measured.

Excision biopsy specimens were received fresh from each patient and were fixed in $10 \%$ buffered formalin, processed, and embedded in paraffin wax. Sections from each were cut and stained with haematoxylin and eosin, toluidine blue, and periodic acid Schiff with and without diastase. Antibodies to IgG (1/2000 dilution) 
Table 1 Clinical information on five cases studied

\begin{tabular}{|c|c|c|c|c|c|c|}
\hline $\begin{array}{l}\text { Case } \\
\text { No }\end{array}$ & Sex & $\begin{array}{l}\text { Age } \\
\text { (months) }\end{array}$ & Site of lesions & Eosinophil counts & Clinical features & $\begin{array}{l}\text { Immunisation histories } \\
\text { from GPs }\end{array}$ \\
\hline 1 & $\mathbf{M}$ & 29 & $\begin{array}{l}\text { Left upper arm, } \\
\text { deltoid region }\end{array}$ & $\begin{array}{l}\text { Postoperative } \\
0.62 \times 10^{9} / 1\end{array}$ & $\begin{array}{l}\text { Two subcutaneous } \\
\text { nodules each } \\
0.5 \mathrm{~cm} \text { in diameter, } \\
\text { itchy }\end{array}$ & $\begin{array}{l}\text { Combined diphtheria/ } \\
\text { tetanus vaccine; first and } \\
\text { second doses into left } \\
\text { shoulder, third dose into } \\
\text { buttock }\end{array}$ \\
\hline 2 & $\mathbf{M}$ & 31 & Right buttock & $\begin{array}{l}\text { Postoperative } \\
0.75 \times 10^{9} / 1\end{array}$ & $\begin{array}{l}\text { Two small } \\
\text { subcutaneous } \\
\text { nodules } 1 \mathrm{~cm} \text { in } \\
\text { diameter, itchy, } \\
\text { tender }\end{array}$ & $\begin{array}{l}\text { Combined } \\
\text { diphtheria/tetanus } \\
\text { vaccine; three } \\
\text { doses into right } \\
\text { buttock }\end{array}$ \\
\hline 3 & $\mathbf{F}$ & 34 & Right buttock & Not done & $\begin{array}{l}\text { One subcutaneous } \\
\text { nodule varying in } \\
\text { size, itchy, } \\
\text { recurrence excised } \\
8 \text { months later }\end{array}$ & $\begin{array}{l}\text { Combined diphtheria/ } \\
\text { tetanus vaccine; three } \\
\text { doses into right buttock }\end{array}$ \\
\hline 4 & $\mathbf{M}$ & 13 & $\begin{array}{l}\text { Left upper arm, } \\
\text { deltoid region }\end{array}$ & $\begin{array}{l}\text { Preoperative } \\
0.24 \times 10^{9} / 1 \\
\text { postoperative } \\
0.2 \times 10^{9} / 1\end{array}$ & $\begin{array}{l}\text { Several ill defined } \\
\text { subcutaneous } \\
\text { nodules, itchy, } \\
\text { tender }\end{array}$ & $\begin{array}{l}\text { Triple vaccine, measles; all } \\
\text { doses into left shoulder }\end{array}$ \\
\hline 5 & $\mathbf{M}$ & 25 & $\begin{array}{l}\text { Left flank, right } \\
\text { buttock }\end{array}$ & $\begin{array}{l}\text { Postoperative } \\
0.46 \times 10^{9} / 1\end{array}$ & $\begin{array}{l}\text { Two ill defined } \\
\text { lumps, one right } \\
\text { buttock } 0 \cdot 2-0 \cdot 3 \mathrm{~cm} \\
\text { in diameter (not } \\
\text { biopsied), other } \\
\text { left flank above } \\
\text { illae crest } 1 \mathrm{~cm} \text { in } \\
\text { diameter } \\
\text { (biopsied), itchy }\end{array}$ & $\begin{array}{l}\text { Triple vaccine, measles; all } \\
\text { doses probably into } \\
\text { buttock; mother } \\
\text { voluntarily related lesions } \\
\text { to immunisations }\end{array}$ \\
\hline
\end{tabular}

and $\operatorname{IgM}, \operatorname{IgA}$ and $\operatorname{IgE}$ (1/400 dilution) obtained from Dakopatts were applied to $4 \mu \mathrm{m}$ sections and visualised using a peroxidase-antiperoxidase method.

\section{Results}

All the biopsy specimens showed essentially similar histological appearances. The ill defined subcutaneous nodules consisted of a prominent inflammatory infiltrate, with numerous small lymphocytes, plasma cells, macrophages and well formed follicles, together with areas of fibrosis and proliferation of small and medium sized vessels often associated with aggregates of eosinophils (fig 1). Endothelial cells were plump but not atypical and mitoses were not identified. Scattered mast cells were present throughout the lesions.

Immunohistochemical preparations showed a consistent distribution of staining. Single cells expressing cytoplasmic IgG were present both within and without follicles with occasional small groups in the mantle zone (fig 2a). There was reticular staining of germinal centres with both IgM and IgE antibodies and occasional IgM positive and IgE positive plasma cells elsewhere (figs $2 b, c)$. (Control material, including human tonsil, lymph node and bowel, showed variable reticular staining of germinal centres with IgM antibodies but these were consistently negative with IgE antibodies.) Some mast cells stained faintly with IgE antibodies. A few plasma cells also stained. positively with IgA antibodies (fig $2 \mathrm{~d}$ ). Macrophages expressed $\alpha_{1}$-antitrypsin and endothelial cells stained only with antibodies to factor VIII antigen (fig 3) (table 2).

Eosinophil counts were obtained in four cases, usually postoperatively (table 1 ). Absolute eosinophilia (eosinophil count $\left.>0.4 \times 10^{9} / 1\right)$ was found in three patients (cases 1, 2, and 5).

A positive history of immunisation at the appropriate site was obtained in four patients (cases 1, 2,3 , and 4 ). In the fifth patient documentary evidence from the general practitioner was less conclusive, although the mother associated the lesions with immunisation. (table 1).

\section{Discussion}

There has been much debate as to the nature of angiolymphoid hyperplasia with eosinophilia and its relation to similar conditions, in particular Kimura's disease. ${ }^{41112}$ Rosai believes that angiolymphoid hyperplasia with eosinophilia is a vascular neoplasm with proliferation of atypical endothelial cells. ${ }^{4} \mathrm{He}$ considers it a separate entity from Kimura's disease which shows features more suggestive of a reactive process. Other workers also prefer to separate the two, ${ }^{11}{ }^{12}$ while still others consider them to be the same condition. ${ }^{313}$

We have not drawn a distinction between angiolymphoid hyperplasia with eosinophilia and Kimura's 

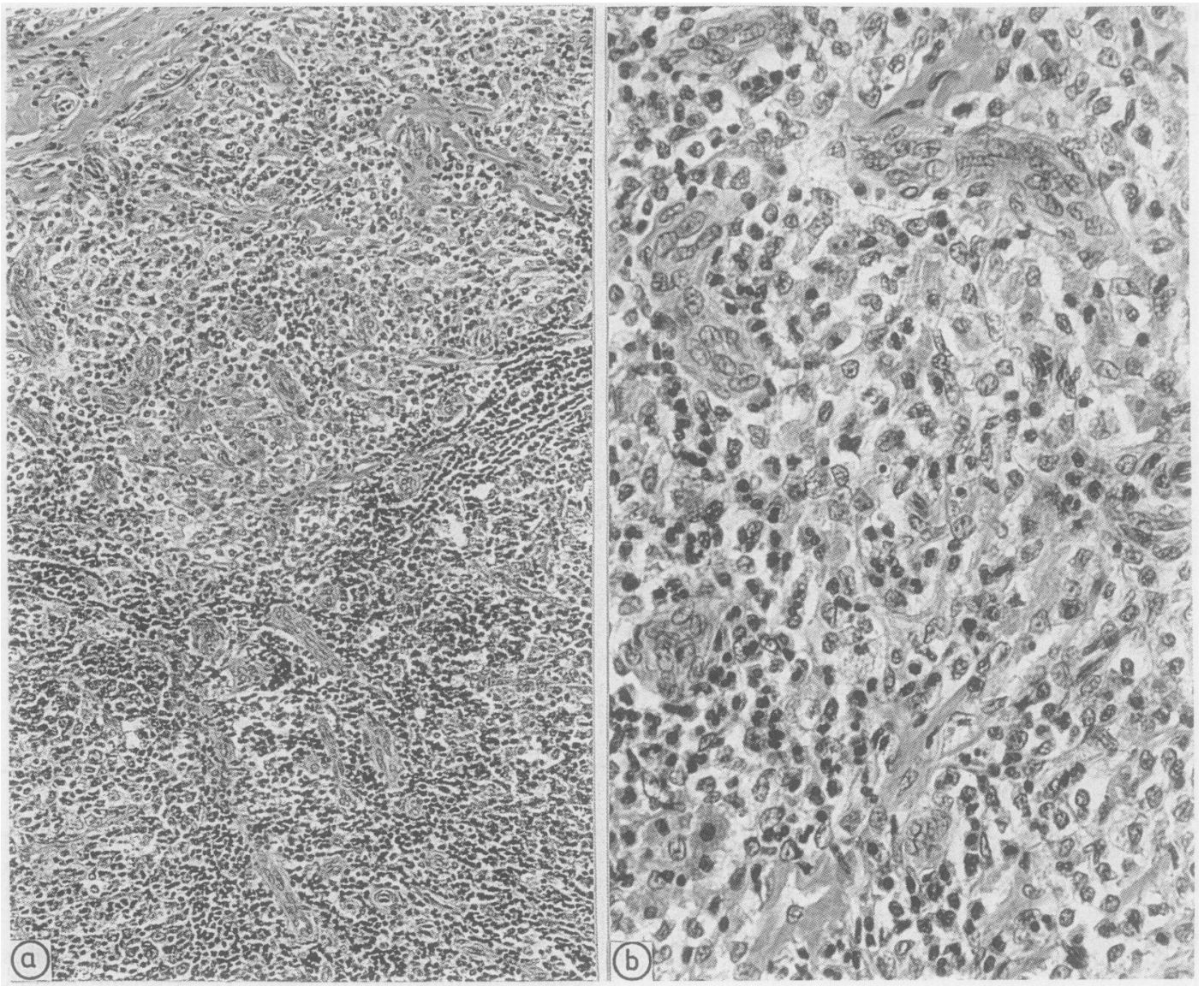

Fig 1 Case 3 (a) Histological features of angiolymphoid hyperplasia with eosinophilia showing inflammatory infiltrate and vascular proliferation. (b) Higher power to show plump but not atypical endothelial cells. (Haematoxylin and eosin.)

disease and our cases are reported as angiolymphoid hyperplasia with eosinophilia. The histological and immunohistochemical appearances would certainly favour a reactive rather than neoplastic process, and if a distinction were to be made then our cases should perhaps be included in Kimura's disease. ${ }^{11} 12$

The immunohistochemical results in our cases are similar to those published for either Kimura's disease $^{51314}$ or angiolymphoid hyperplasia with eosinophilia. ${ }^{15}$ Published results were obtained using paraffir. wax sections, ${ }^{615}$ or frozen sections, ${ }^{5}$ or both. ${ }^{14}$ All these papers report a pronounced reticular staining of germinal centres with IgE antibodies. Only a few isolated cells stained with antibodies to IgA. There was variable staining of germinal centres and B cells with IgG and IgM antibodies.

As expected the vascular endothelium expressed factor VIII antigen and this parallels results obtained by Wright et al. ${ }^{15}$ Some workers have described the endothelium in angiolymphoid hyperplasia with eosinophilia as having an atypical "histiocytoid" appearance, ${ }^{4}$ but in our cases there was no evidence of this, and $\alpha_{1}$-antitrypsin stained only macrophages.

Eosinophils were prominent in our cases and seemed to aggregate in the areas of vascular proliferation. Mast cells were distributed throughout the lesions and did not seem to be particularly associated with the eosinophils. This distribution was similar to that described by Ishikawa et al,$^{6}$ although Takenaka et $a l^{5}$ thought mast cells were aggregated in areas rich in eosinophils.

The appearances in the histological sections are those of a reactive process. The aetiology of angiolymphoid hyperplasia with-eosinophilia remains obscure, although an allergic reaction has been proposed. $^{5111215}$ Blood eosinophilia and raised serum 

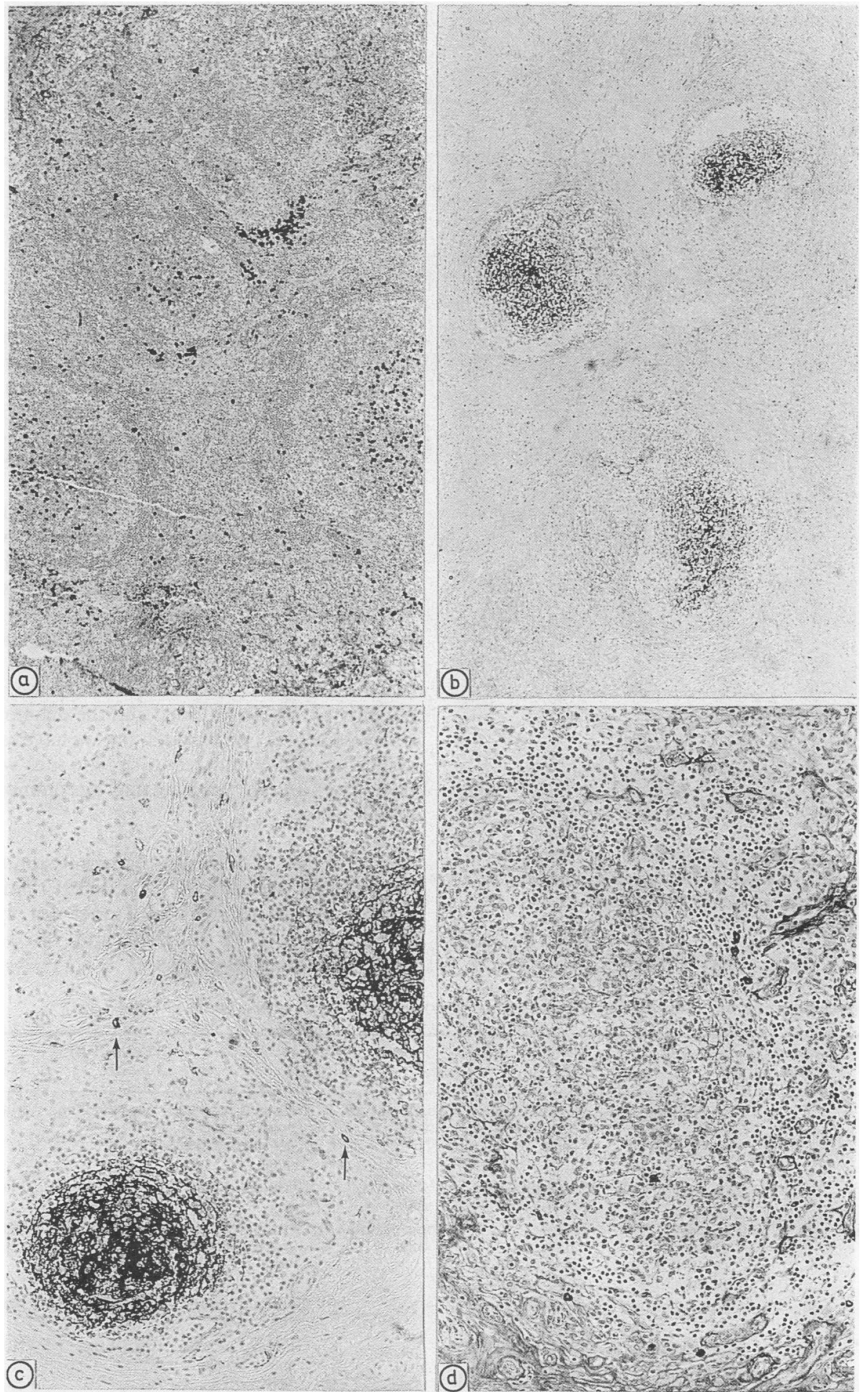

Fig 2 Immunohistochemical staining for immunoglobulin heavy chains. (a) Case 3: IgG antibodies staining moderate numbers of cells within and without follicles. (b) Case 5: IgM antibodies giving a reticular staining pattern of germinal centres. Occasional plasma cells outside follicles also stained (not illustrated). (c) Case 3: IgE antibodies also gave a reticular staining of germinal centres, and single plasma cells are also seen staining positively (arrows) and some mast cells stained faintly (not illustrated). (d) Case 1: scattered plasma cells stained with antibodies to IgA. 


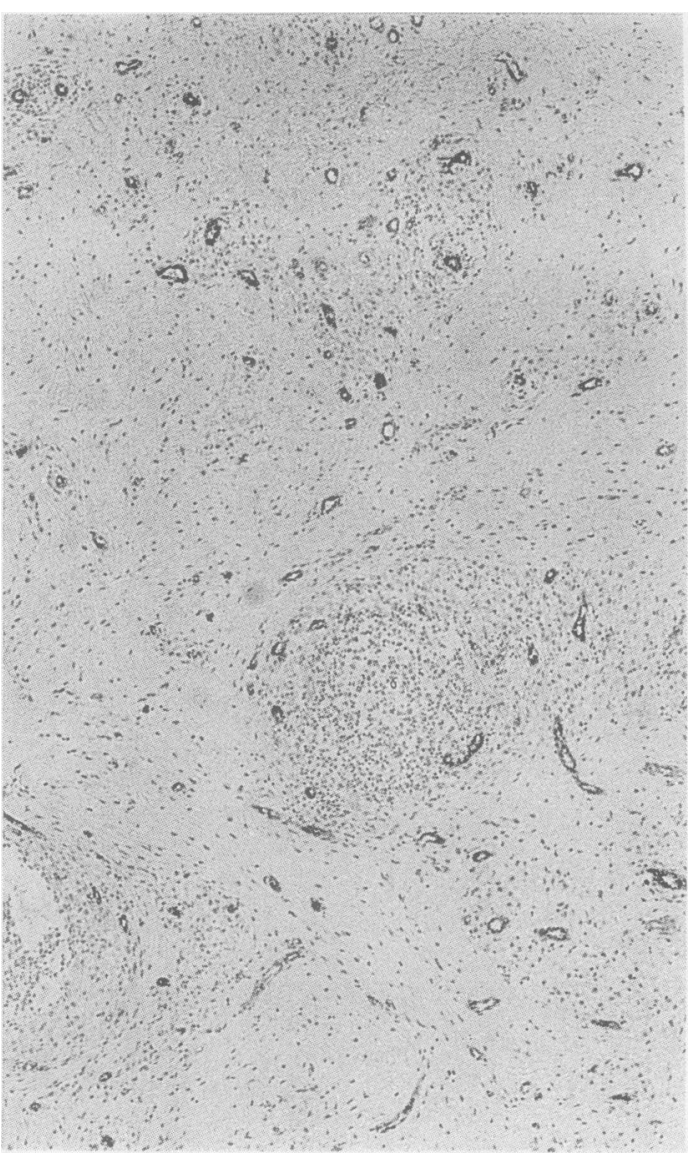

Fig 3 Case 5: staining of endothelium with antibodies to factor VIII antigen highlights the vascular proliferation. Endothelial cells did not stain with antibodies to $\alpha_{1}$-antitrypsin.
IgE concentrations have been reported with lesions described as both Kimura's disease and angiolymphoid hyperplasia with eosinophilia, although they are more common in the former. ${ }^{12}$ The presence of a blood and tissue eosinophilia and raised serum IgE concentrations further suggests an allergic aetiology and, indeed, atopic allergy to Candida albicans has been postulated by Takenaka $e t$ al..$^{5}$

All our patients presented within the first few years of life and the consistent distribution of lesions (upper arm and buttock) struck us as unusual. We were alerted to the possible role of immunisation in their development and indeed the mother of one patient (case 5) volunteered that the lesions developed shortly after immunisation. The remarkable correlation of injection sites (combined diphtheria/tetanus in cases 1 , 2 , and 3 and triple vaccine in cases 4 and 5) with the distribution of lesions is particularly noteworthy (table 1). Measles immunisation was given only in cases 4 and 5.

While it is difficult to prove conclusively an aetiological role for immunisation in the development of angiolymphoid hyperplasia with eosinophilia in our cases, the evidence certainly suggests an association. We have been unable to find any previously published report of such an association. The pathogenesis of this condition may well be multifactorial and our cases illustrate only one aspect of the disease. Only five patients have been biopsied and the diagnosis proved histologically at our hospital, but we have seen severaB clinically similar nodules in similar sites which were not excised and the problem may be commoner than it at first seems.

We thank Mr W H Bisset for permission to publish details of his patient (case 3) and Dr I I Smith for his advice. We thank Mrs S Turner for typing the manuscript and $\mathrm{Mr} \mathrm{L}$ Brett and $\mathrm{Mr} \mathrm{J}$ Paul for producing the photographs.

Table 2 Immunohistochemical results in five cases and comparison with results of previously published work

\begin{tabular}{|c|c|c|c|c|c|c|c|}
\hline & $\begin{array}{l}\text { No of } \\
\text { cases }\end{array}$ & IgG & $\operatorname{Ig} M$ & $\operatorname{Ig} A$ & $\operatorname{Ig} E$ & $\begin{array}{l}\text { Factor VIII } \\
\text { antigen }\end{array}$ & $\alpha_{1}$-antitrypsin \\
\hline Hallam et al & 5 & $\begin{array}{l}\text { Many plasma } \\
\text { cells }\end{array}$ & $\begin{array}{l}\text { Germinal centres, } \\
\text { few plasma } \\
\text { cells }\end{array}$ & $\begin{array}{l}\text { Some plasma } \\
\text { cells }\end{array}$ & $\begin{array}{l}\text { Germinal centres, } \\
\text { some plasma } \\
\text { cells, some mast } \\
\text { cells }\end{array}$ & Endothelium & Macrophages \\
\hline Wright et al ${ }^{15}$ & 1 & $95 \%$ plasma cells & $4 \%$ plasma cells & $\begin{array}{l}1 \% \text { plasma } \\
\text { cells }\end{array}$ & Germinal centres & Endothelium & Macrophages \\
\hline Ishikawa et $a l^{6}$ & 46 & $\begin{array}{l}\text { Variable } \\
\text { germinal } \\
\text { centres, some } \\
\text { plasma cells }\end{array}$ & $\begin{array}{l}\text { Variable } \\
\text { germinal } \\
\text { centres, some } \\
\text { plasma cells }\end{array}$ & $\begin{array}{l}\text { Some plasma } \\
\text { cells }\end{array}$ & $\begin{array}{l}\text { Germinal centres, } \\
\text { many plasma } \\
\text { cells }\end{array}$ & Not done & Not done \\
\hline $\begin{array}{c}\text { Takenaka } \\
\text { et } a l^{5}\end{array}$ & 10 & Germinal centres & Germinal centres & - & Germinal centres & Not done & Not done \\
\hline Maeda et $a l^{14}$ & 1 & $\begin{array}{l}\text { Germinal centres, } \\
\text { some single } \\
\text { cells }\end{array}$ & $\begin{array}{l}\text { Germinal centres, } \\
\text { some single } \\
\text { cells }\end{array}$ & - & $\begin{array}{l}\text { Germinal centres, } \\
\text { many single } \\
\text { cells }\end{array}$ & Not done & Not done \\
\hline
\end{tabular}




\section{References}

1 Olsen TG, Helwig EB. Angiolymphoid hyperplasia with eosinophilia. A clinicopathologic study of 116 patients. J Am Acad Dematol 1985;12:781-96.

2 Lever WF, Schaumburg-Lever G. Histopathology of the skin. Sixth ed. Philadelphia: J B Lippincott Company, 1983.

3 Wells GC, Whimster IW. Subcutaneous angiolymphoid hyperplasia with eosinophilia. Br J Dermatol 1969;81:1-15.

4 Rosai J. Angiolymphoid hyperplasia with eosinophilia of the skin. Its nosological position in the spectrum of histicytoid haemangioma. Am J Dermatopathol 1982;4:175-84.

5 Takenaka T, Okuda M, Usami A, et al. Histological and immunological studies on eosinophilic granuloma of soft tissue, so-called Kimura's disease. Clin Allergy 1976;6:27-39.

6 Ishikawa E, Tanaka H, Kakimoto S, et al. A pathological study on eosinophilic lymphfolliculoid granuloma (Kimura's disease). Acta Pathol Jpn 1981;31:767-81.

7 Moesner J, Pallesen R, Sorensen B. Angiolymphoid hyperplasia with eosinophilia (Kimura's disease). A case with dermal lesions in the knee region and a popliteal arteriovenous fistula. Arch Dermatol 1981;117:650-3.

8 Van Gulik TM, Jansen JW, Taat CW. Kimura's disease in the spermatic cord, an unusual site of a rare tumour. Netherlands $J$ Surg 1986;38:93-5.

9 Fornasier VL, Finkelstein S, Gardiner GW, Wong D. Angio- lymphoid hyperplasia with eosinophilia: a bone lesion pathologically resembling Kimura's disease of skin. A report of two cases. Clin Orthop 1982;166:243-8.

10 Rao RN, Spurlock BO, Witherington R. Angiolymphoid hyperplasia with eosinophilia: report of a case with penile lesions. Cancer 1981;47:944-9.

11 Kung ITM, Gibson JB, Bannatyne IP. Kimura's disease: a clinicopathological study of 21 cases and its distinction from angiolymphoid hyperplasia with eosinophilia. Pathology 1984; 16:39-44.

12 Googe PB, Harris NL, Mihm MC. Kimura's disease and angiolymphoid hyperplasia with eosinophilia: two distinct histopathological entities. J Cutan Pathol 1987;14:263-71.

13 Henry PG, Burnett JW. Angiolymphoid hyperplasia with eosinophilia. Arch Dermatol 1978;114:1168-72.

14 Maeda K, Jimbow K. Kimura's disease: Immunohistochemistry of infiltrating cells using monoclonal and polyclonal antibodies. $J$ Dermatol 1986;13:190-5.

15 Wright DH, Padley NR, Judd MA. Angiolymphoid hyperplasia with eosinophilia simulating lymphodenopathy. Histopathology 1981;5:127-40.

Requests for reprints to: Dr L A Hallam, Department of Pathology, Royal Hospital for Sick Children, 2 Rillbank Crescent, Edinburgh, Scotland. 